\title{
The Relationship Between Financial Flexibility and Market Value Added: The Mediation Effect Role of the Corporate Size (A Practical Study on a Sample of Jordanian Industry Sector Firms)
}

\author{
Arshed Fouad Altameemi ${ }^{1}$ \\ ${ }^{1}$ Department of Business Administration and Accounting, AL Buraimi University College, Oman \\ Correspondence: Arshed Fouad Altameemi, Professor in Finance, Department of Business Administration and \\ Accounting, AL Buraimi University College, Oman. E-mail: altameemiarshed@gmail.com
}

Received: November 9, 2020

Accepted: December 3, 2020 Online Published: December 10, 2020

doi:10.5539/ijef.v13n1p52

URL: https://doi.org/10.5539/ijef.v13n1p52

\begin{abstract}
The current study aims at testing the effect of 'Financial Flexibility' (FF) on the market value-added by the firm size as a mediator variable. This study's statistic sample consists of 26 companies listed on the Amman stock exchange from 2010 to 2019. The FF and market value-added are independent and dependent variables, respectively. The data analysis was done by the Baron - Kenny methodology (1986) and Sobel-Test to analyze the hypothesizes based on the corporate size's mediation effect role. The results concluded from the study of the effect of the company size on the relationship between FF and market value-added stated that the FF has a positive statistically significant impact, and there a partial mediation of the firm size effect upon this relationship due to the mediation effect is statistically significant based on Sobel test.
\end{abstract}

Keywords: Financial Flexibility (FF), Spare Financial Leverage (SFL), Market Value Added (MVA), meditation, size, Baron and Kenny, and Sobel test

\section{Introduction}

The notion of FF has been more interested, especially after the last global crisis of 2008. It is one of the essential matters of a corporation's capital structure design. Besides, it enables organizations to pursue profitable investment opportunities, leading to stable growth in the long term. Moreover, FF is considered one of the issues of corporate financial leverage and a guide for the management to maintain suitable debt arrangements, which will sustain the fund flow in a time of unexpected growth opportunities. Corporations with high FF are more capability to avoid unfavorable financial shakes and enter the financial market to meet their financing needs toward profitable opportunities (Gamba \& Triantis, 2008, p. 2263, Arslan et al., 2014, 190). Whereas firms with low FF will hard suffer from limited funding, they will lose their capability to get funding from external sources to pursue growth opportunities (Poulson et al., 2013, p. 327). Most recent literature connects FF with low financial leverage and high cash holding (Bates et al., 2008, 1985-2021). Moreover, please connect to the corporate ability to arrange the funding priorities of investment opportunities to avoid the additional business risks generated from adjusting capital structure to its unexpected resources' unexpected needs. In other words, the flexible firm can crowd additional financial resources to take preventive arrangements for future unconfirmed emergencies and to maintain its value (Byon, 2008, cited in Chue, 2012, p. 225).

From the aforementioned, companies tend to take a low debt policy to avoid or reduce bankruptcy costs (Graham, 2000). Besides, support capability to enter the debt and equity markets and provide defense procedures for future urgent cases to maintain the firm value (Chue, 2012). Firms are a tendency to take lower leverage policy (spare financial leverage) to sustain the FF (Marchica \& Mura, 2010, 1340-1343), whether from its operating cash flows of business and borrow from debt markets in the line of optimal capital structure (Hess \& Philip, 2014, p. 24).

\section{Conceptual Framework and Literature Review}

\subsection{Conceptual Framework of the Study}

Rayan (2007) stated that FF is the firm's ability to move its financial resources toward activities that will achieve the firm's goal of value maximization (Cited in Darabi et al., 2013, p. 3843). Others stated that FF is the cash holding of a firm and available credit line in the banking markets (Lozana, 2012, p. 2696). Darabi et al. (2013) 
connected FF's concept with a lower dividend payout ratio and financial leverage if the firm will suffer from fluctuate its net cash flows. Ma and Jin (2016) measure FF considered firms liquidity, leverage, and internal funds. Internal fund and Spare financial leverage (Debt Capacity) seem to be critical drivers of a firm's FF in the recent capital structure literature. The company Manager focuses on using the financial leverage level based on balancing the cost-benefit principle (Brigham \& Ehadart, 2011, p. 843).

Setianto and Kusumaputra (2017) stated that FF is a firm's ability to mobilize its financial resources in facing future uncertainties. Therefore, management strives to keep highly spare financial leverage to augment debt capacity and avoid the increased cost of potential debt risk and reduce its value (market stock price).

Technological and asset quality considered a suitable guarantee of a firm's debt capacity and qualify the firm to enter the credit market and reduce the agency problem of debt cost (Ogden \& Wu, 2013). On the other side, the liquid degree of working capital (as a part of a total asset) also plays a crucial role in supporting the debt guarantee and then FF. While debt serving capacity focuses on a firm's ability to pay debt interest from operating cash flows and free cash flows (Kolker, 2013, p. 32), in other words, the firm with high debt serving capacity is a flexible firm and versa. So, debt serving capacity affects the stock price of the firm. However, the free cash flows subject to interest conflict hypotheses among owners and managers and creates agency problems (Bhundia, 2012). However, good governance of cash flows will able the firm to serve the debt and qualified it to adjust leverage to actual financial needs and then enhance the FF (Thanatawee, 2011, p. 53).

Chughtai et al. (2011, p. 557) define free cash flow as cash generated from the activity, which can be distributed to stockholders as dividends without compromising the current growth level. Rising free cash flow will improve FF and support the trust of creditworthiness. Coskun and Kulalı (2012) stated that companies with regular cash flows might have a higher credit score than companies with fluctuations in cash flows. Companies with positive free cash flow have high FF to pursue profitable investment toward increasing their market share prices.

\subsection{Literature Review}

Multiple studies tried to exam FF in the empirical review, whether used a single index or numerous indexes for measuring FF. Lemmon and Zender (2008) stated that the fund generated from internal (operating cash flows) is the best source to finance the investment, and they proved that the profitable firms strive to keep low financial leverage (low debt capacity). Wang (2010) stated that the free cash flow would be generating due to asset utilization efficiency. Therefore, there is a positive relationship between free cash flow and firm performance. Liow (2010) proved that firms have FF when they keep a low debt ratio. This ratio (current ratio minus previous ratio) considers a one-off out crucial indicators that affect the firm's market value. Marchica and mora (2010) reveal that firms make more massive capital expenditures and increase abnormal investment following a period of low leverage (Low spare financial leverage). These new investments are financed through recent issues of debt. Bancel and Mittoo (2011) tested France's firm's FF after the global crisis 2008; they found some firms not suffered from the problem due to low financial leverage would be allowed it borrow to meet financial distress.

Iqbal, Hameed, and Ramzan (2012) found a positive correlation between debt capacity and the market-to-book ratio of sample firms listed in the Karachi stock exchange. Moreover, it means low financial leverage would allow it to borrow to meet the additional financial needs without substantial financial risk. Ogden and Wu (2013) concluded a strong negative correlation between market-based optimal financial leverage ratio and growth options of American companies' sample. This relationship represents a core effect on corporate management decisions to pursue investment opportunities.

Darabi, Mohammadi, Ghasmi, and Forozan (2013) tested the relationship between FF and capital structure decisions for 82 firms listed in the Tehran stock exchange. They used (cash holding, research and development disbursements, dividend changing, and fixed asset changing) as proxy variables of FF. They concluded that the suitable extra cash holding played a crucial effect on the common stock's abnormal return. Hando and Sharma (2014) used a variety of debt serving capacity (times interest earns ratio) as a proxy of FF of (870) listed firms on the Bombay securities market. They concluded that debt serving capacity affects capital structure decisions besides growth rate, firms' size, cost of debt, and tax.

Yung et al. (2015) examined the effects of flexibility in emerging countries. They showed that flexibility could enhance a firm's investment ability and reduce its investment sensitivity from cash flows. The authors state that flexibility has a more significant effect during a global economic crisis. Flexible companies cut less funding from their investment levels than inflexible firms and better overall operating performance. Mirkhalili and Mahmoudabadi (2018) stated that FF has positive and meaningful effects on companies' investment activity. Islam, Wang, and Zulfiqar (2019) tested corporate governance's impact on firms' FF in the Emerging Economic: Evidence from Bangladesh. They used the debt capacity of the firm as indexes for measuring FF. They concluded 
that the ownership structure has no positive impact on FF. However, Financial Constraints and the market-to-book value ratio have a significant positive effect on unused debt capacity.

In contrast, firm Size has a positive relationship with internal funds. Al-Slehat (2019) stated a positive impact of the FF measured by the cash flows, cash holding, and liquidity on the performance indicators (interest coverage ratio, operating margin ratio) in the Jordanian services sector firms. The study benefits from cognitive contributions of prior studies to enrich the current study conceptual framework and to clarify the FF in the light of the following issues: -

1) The present research focuses on long-term debt rather than total debt to calculate spare financial leverage because it is riskier than short-term debt. Long-term debt financing increases will dilute the value of common stocks.

2) Use spare of financial leverage in relationship with the market value added in the emerging market.

3) The research focused on analyzing FF in the emerging stock market after the global crisis in 2008.

4) This study is extended of Al-Slehat study (2019) conducted on Jordanian services sectors, whereas this study is doing in the Jordanian industry sector with different variables.

5) The current study conducts the full or partial mediation variable of the firm size in the effect framework.

\section{Methodology and Model Specification}

\subsection{Statement of Problem}

FF's main problem is the missing link between capital structure theories (DeAngelo \& DeAngelo, 2007). Although there are many contributions to the study of capital structure, notably Modigliani and Miller's theory $(1958,1961)$, among other studies, the effect of optimal financial leverage on the firm's value maximization still exists. Thus, FF is considered one of the management's difficult decisions to determine the appropriate financial leverage level. Moreover, it needs interest from researchers and writers to determine theoretical concepts and their drivers. Besides, it is crucial to improve the corporate capability to select suitable debt policies and cash flows. Despite the FF concept being more attractive after the global crisis in 2008, numerous questions have not received an adequate amount of attention (Islam et al., 2019, p. 254). The missing link of capital structure theories and no consensus between researchers and writers about the indicators that reflect corporations' FF in the developing financial markets especially. Based on this problem framework, the importance of examining the relationship between FF and market value added in the Jordanian financial market to achieve the research goal in line with the two main questions

1) Is there a relationship between financial flexibility and the firm's market value added?

2) Does the firm's size show a full or partial mediation effect on financial flexibility and market value-added relationships?

\subsection{Model Specification of Study}

The following model is adapted to present the specific views of the problem, questions, and its features concerning the impact of the Firm size (mediator variable) on the relation between spare financial leverage and market value-added, as follows:

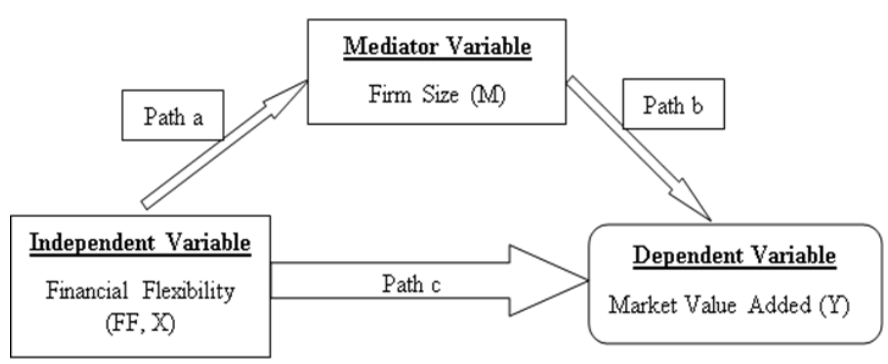

Figure 1. The model of study

\subsection{Hypotheses of the Study}

Based on the study model, formulating the following hypothesizes: 
$\mathrm{H}_{1}$ : There is no statistically significant relationship at $(\alpha \geq 0.05)$ between FF (spare financial leverage) and market value-added.

$\mathrm{H}_{2}$ : There is no statistically significant relationship at $(\alpha \geq 0.05)$ between FF and firm size.

$\mathrm{H}_{3}$ : There is no statistically significant relationship at $(\alpha \geq 0.05)$ between the firm size and market value-added.

$\mathrm{H}_{4}$ : There is no statistically significant effect at $(\alpha \geq 0.05)$ of the firm size (mediator variable) on the relationship between Financial Flexibility and market value-added.

\subsection{Population and Sample of Study}

The study population is all the industrial companies listed on the Amman Stock Exchange. The research can apply to this sector due to facilities and qualify for access to the data and other needed information to calculate the research variables. Twenty-six companies out of listed industry firms were chosen as a statistic sample, which constituted approximately $16 \%$ of the study population. Wherein the following conditions met during the period (2010-2019):

1) The annual financial reports are available to each company during the period to obtain the most significant possible amount of data needed to calculate study variables.

2) There is continuous trading of stock in the mentioned stock market during the period of study.

3) There is no merger of the sample companies or under liquidation during the study period.

4) In the line with the study of Marchica and Mora (2010), the sample must have at least three consecutive years spare of financial leverage to classify it as FF.

\subsection{Data Collection}

The theoretical foundation and literature review are collecting by using scientific periodical, journal, and books. The data and information needed for testing the hypothesize were extracted by reference to the financial reports of sample firms published at the Amman stock exchange website.

\subsection{Statistical Methods Were Used to Test the Hypothesis.}

The study adopted Baron and Kenny's methodology (1986) to test and analyze the hypothesizes based on the mediator variable role. An independent variable (FF) affects a distal dependent variable (MVA) through a mediating variable (Firm Size), as shown in figure 1; this methodology recommended three conditions (Baron \& Kenny, 1986, 1176):

1) Variations in the independent variable levels significantly account for variations in the presumed mediator (i.e., path a).

2) Variations in the mediator significantly account for variations in the dependent variable (path b)

3) When Paths a and b are controlled, a previously significant relation between the independent and dependent variables is no longer significant, with the most important demonstration of mediation occurring when path $\mathrm{c}$ is zero.

Noted that condition (c) requires a significance test for direct path $\mathrm{c}$, the path $\mathrm{a}, \mathrm{b}$, and $\mathrm{c}$ are tested and estimated by the following three equations (Zhao et al., 2010, p. 198):

$$
\begin{gathered}
M=i_{1}+a X_{+} e_{1} \\
Y=i_{2}+c^{\prime} X_{+} e_{1} \\
Y=i_{3}+c X_{+} b M+e_{1}
\end{gathered}
$$

Baron and Kenny recommended testing the indirect path $(\mathrm{a} \times \mathrm{b})$ by the Sobel test to examine the statistical significance of the difference between the total effect and the direct effect. This test requires an estimate of a standard error of the mediation path (ab) (Hayes, 2009, p. 411). In other words, it interprets whether the reduction in the effect of the independent variable, including the mediator in the model, is significant and; therefore, whether the mediation effect is statistically significant.

\subsection{Operational Definition of Study Variables and Measurement}

1) Financial flexibility (independent variable)

Spare financial leverage (SFL) seems to be a critical driver of a firm's FF in the recent capital structure literature (Marchica \& Mura, 2010; Ma \& Jin, 2016). Cherkasova and Kuzmin (2018) define FF as spare debt capacity; it is a Spare financial leverage function. SFL calculated based on the current financial leverage ratio (CFL) deviation 
from the average (proxy expected, EFL) of the study period (Mirkhalili \& Mahmoudabadi, 2018, p. 148):

$$
S F L=C F L-E F L= \pm
$$

A negative spare financial leverage means the firm has unused debt capacity and classifies it as a flexible financial firm; otherwise, it is inflexible in the case of positive.

2) Market Value Added (Dependent Variable Y)

Market value added (MVA) is the second indicator marketed by Stern Stewart in 1991 to evaluate a corporation's performance. It is the value arising from exceeding the market value of capital over the book value; therefore, it is a cumulative measure of the returns to the capital (Alipour \& Pejman, 2015, p. 9). This variable is considered an essential tool that investors and analysts are carefully monitoring to make crucial financial decisions. This attitude pays the researcher to detect the relationship with FF. One of the most common methods of calculating MVA is the difference between the market value of total equity and the book value of those rights as follows (Brigham \& Ehrhardt, 2011, p. 67):

$$
M V A=\left(\text { Market stock price }{ }^{x} \text { number of stock }\right)-B V E= \pm
$$

\section{3) Firm Size (Mediator Variable)}

Company size proxied by asset possession is a salient corporate characteristic (Dang \& $\mathrm{Li}, 2014$ ). For the study purposes, the study will use the natural logarithm of total assets (LOGTA) as an indicator of the size (Talebnia et al., 2010, p. 268).

\section{Discussion}

\subsection{Descriptive Analysis}

Table 1 shows the statistical descriptive of the study variables. It illustrates the mean and the standard deviations for the independent variable, the FF, measured by spare financial leverage, and the dependent variable, market value added (MVA). It reveals that there is a convergence of results of the variables despite the difference in age and size of the population; this reflects the efficiency of the operational process that led to an increase in the market value-added.

Table 1. Statistical descriptive of the study variables

\begin{tabular}{cccc}
\hline Variables & Observations & Mean & Std. Deviation \\
\hline SFL & 260 & 12.81 & 4.235 \\
LOGTA & 260 & 11.741 & 3.181 \\
MVA & 260 & 9.039 & 2.6714 \\
\hline
\end{tabular}

\subsection{Person Correlations Matrix Analysis}

Table 2 reflects the correlation coefficients matrix between the study variables. It reveals that all coefficients are positive and significant statistical at level $1 \%$.

Table 2. Person correlation matrix of study variables ${ }^{*}$

\begin{tabular}{cccc}
\hline & SFL & LOGTA (Size) & MVA \\
\hline SFL & 1 & 0.682 & 0.612 \\
LOGTA (Size) & 0.682 & 1 & 0.677 \\
MVA & 0.612 & 0.677 & 1 \\
\hline
\end{tabular}

* correlation is significant at the 0.01 level (2 tailed)

\subsection{Analysis of First Hypothesis Testing Results}

Table 3 presented the Autocorrelation test and simple regression results for the $1^{\text {st }}$ hypothesis. The Durbin-Watson value (2.042) shows no autocorrelation exists amongst the regression equation's errors due to within acceptable limits of $0-4$. Hence, the F-test results show the rejection of the null hypothesis $\left(\mathrm{H}_{01}\right)$ and the acceptance of the alternative hypothesis $\mathrm{H}_{11}$. It can also explain that the spare financial leverage affects the market value added values, as the estimated F-values are significant with a $p$-value lesser than $5 \%$. The model also possesses an explanatory power for SFL, with an $\mathrm{R}^{2}$ coefficient value of 0.375 . This result indicates that the mean values of SFL can explain $37.5 \%$ of the variation in the MVA. 
Table 3. Test results for the first hypothesis (Path c)

\begin{tabular}{lllll}
\hline Dependent Variable (MVA) & & & & \\
\hline Independent Variable & Beta & Std. Error & T-TEST & Sig. \\
SFL & 0.386 & 0.031 & 12.43 & 0.000 \\
\hline $\mathrm{R}$ & $\mathrm{R}^{2}$ & Durbin-Watson & F Calculated & Sig. \\
0.612 & 0.375 & 2.042 & 154.5 & 0.000 \\
\hline
\end{tabular}

\subsection{Analysis of Second Hypothesis Testing Results}

In Table 4, the researcher has presented the Autocorrelation test and simple regression results for the $2^{\text {nd }}$ hypothesis. The Durbin-Watson value (1.87) shows no autocorrelation exists amongst the regression equation's errors within acceptable limits of 0-4. Hence, the F-test results show the rejection of the null hypothesis $\left(\mathrm{H}_{02}\right)$ and the acceptance of the alternative hypothesis $\mathrm{H}_{12}$. Also, it can see that the spare financial leverage affects the size of the firm (LOGTA), as the estimated F-values are significant, with a p-value lesser than 5\%. The model also possesses an explanatory power for SFL, with an $\mathrm{R}^{2}$ coefficient value of 0.465 . This result indicates that the mean values of SFL can explain $46.5 \%$ of the variation in the LOGTA.

Table 4. Test results for the second hypothesis (Path a)

\begin{tabular}{lllll}
\hline Dependent Variable (LOGTA) & & & & \\
\hline Independent Variable & Beta & Std. Error & T-TEST & Sig. \\
SFL & 0.512 & 0.034 & 14.98 & 0.000 \\
\hline $\mathrm{R}$ & $\mathrm{R}^{2}$ & Durbin-Watson & F Calculated & Sig. \\
0.682 & 0.465 & 1.87 & 224.388 & 0.000 \\
\hline
\end{tabular}

\subsection{Analysis of Third Hypothesis Testing Results}

Table 5 shows that no autocorrelation exists amongst the regression equation's errors due to the value of Durbin-Watson within acceptable limits of 0-4. Hence. The F-test results show the rejection of the null hypothesis $\left(\mathrm{H}_{03}\right)$ and the acceptance of the alternative hypothesis $\mathrm{H}_{13}$. Also, it can see that the firm size (LOGTA) affects the market value added values, as the estimated F-values are significant with a $p$-value lesser than 5\%. The model also possesses an explanatory power for LOGTA, with an $\mathrm{R}^{2}$ coefficient value of 0.458 . This result indicates that the mean values of LOGTA can explain $45.8 \%$ of the variation in the MVA.

Table 5. Test results for the first hypothesis (Path b)

\begin{tabular}{|c|c|c|c|c|}
\hline \multicolumn{5}{|c|}{ Dependent Variable (MVA) } \\
\hline Independent Variable & Beta & & T-TEST & Sig. \\
\hline LOGTA & 0.569 & & 14.78 & 0.000 \\
\hline $\mathrm{R}$ & $\mathrm{R}^{2}$ & Durbin-Watson & F Calculated & Sig. \\
\hline 0.677 & 0.458 & 2.237 & 218.444 & 0.000 \\
\hline
\end{tabular}

\subsection{Analysis of Fourth Hypothesis Testing Results}

The fourth hypothesis explores the effect of the mediator variable (LOGTA) on the relationship between the independent and dependent variables. Based on the Baron and Kenny test, the second and third hypothesis results (path $\mathrm{a}, \mathrm{b}$ ) led to the first and second conditions. The independent variables' beta coefficients were statistically significant and lesser than 5\% (Table 4, 5). The full effect of the path (c) was also statistically significant (Table 3). According to those mentioned above, Table 6 and Figure 2 present the testing result multiple regression of the fourth hypothesis. The independent variable and the mediator's regression coefficient are $(0.177,0.408$ respectively), and they are statistically significant at level $5 \%$. Therefore, the three conditions were provided to reject the fourth null hypothesis and accept the alternative $\left(\mathrm{H}_{14}\right)$. It must mention here, despite the downsizing of the impact coefficient of the spare financial leverage from 0.386 to 0.177 , after including the mediator in the model. However, it is still statistically significant because the firm size's mediator effect is statistically significant at a level lesser than $5 \%$ based on the Sobel test. (Table 7). 
Table 7. Results of the Sobel test

\begin{tabular}{lcccc}
\hline & \multicolumn{2}{c}{ Beta Coefficient } & \multicolumn{2}{c}{ Standard Error } \\
\cline { 2 - 5 } & Path a & Path $\mathrm{b}$ & Path a & Path $\mathrm{b}$ \\
\hline Inputs & 0.512 & 0.408 & 0.034 & 0.031 \\
\hline & Sobel Test $(\mathrm{t})$ & 9.9 .9 & Sig. & 0.000 \\
\hline
\end{tabular}

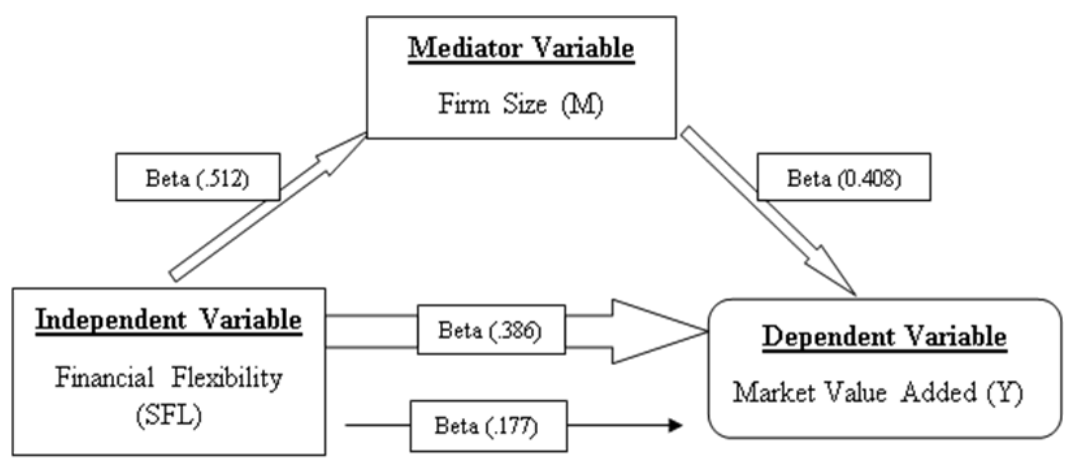

Figure 2. The model of study based on Baron and Kenny Test

\section{Conclusion Remarks}

1) The current study revealed that firms' flexible finances could provide their debt capacity for the next years to finance new profitable investments to maximize market value-added; it is compatible with the results of the study done by DeAngelo and Whited (2007).

2) The current study confirms Byon's result (2007) regarding the relationship between FF and company size (Mirkhalili \& Mahmoudabadi, 2018, p. 153). The study concludes a partial mediation impact of corporation size on the relationship between FF and market value-added. Despite the downside of the spare financial leverage regression coefficient's impact from 0.386 to 0.177 , it is around zero.

3) It is suggested to the investors select the companies with high spare financial leverage due to the potential for increased chance finances the profitable investments with a reasonable cost of the debt. Besides, they provide better income opportunities derived from their investments to maximize the firm's market value.

\section{References}

Alipour, M., \& Pejman, M. E. (2015). The impact of performance measures, leverage, and efficiency on market value added: Evidence from Iran. Global Economics and Management Review, 20, 6-14. https://doi.org/10.1016/j.gemrev.2015.04.001

Arslan, Ö., Florackis, C., \& Ozkan, A. (2014). FF, corporate investment, and performance: Evidence from financial crises. Review of Quantitative Finance and Accounting, 42(2), 211-50. https://doi.org/10.1007/s11156-012-0340-x

Bancel, F., \& Mittoo, U. R. (2004). The Determinants of Capital Structure Choice: A Survey of European Firm. Financial Management, 33, 103-132.

Baron, R. M., \& Kenny, D. A. (1986). The Moderator-Mediator Variable Distinction in Social Psychological Research, Conceptual, Strategic, and Statistical Considerations. Journal of Personality and Social Psychology, 51(6), 1173-1182. https://doi.org/10.1037/0022-3514.51.6.1173

Bates, T. W., Kahle, K. M., \& Stulz, R. M. (2008). Why does our firm hold so much more cash than they used to? Journal of Finance, 64, 1985-2021. https://doi.org/10.1111/j.1540-6261.2009.01492.x

Bhundia, A. (2012). A Comparative Study Between Free Cash Flows and Earnings Management. Business Intelligence Journal, 5(1), 123-129.

Brigham, E. F., \& Ehrhardt, M. C. (2011). Financial Management (13th ed.). South-Western, USA.

Cherkasova, V., \& Kuzmin, E. (2018). FF as an Investment Efficiency Factor in Asian Companies. Gadjah Mada International Journal of Business, 20(2), 137-164. https://doi.org/10.22146/gamaijb.26239

Chongyu, David, D., \& Frank, L. (2014). Measuring firm size in empirical corporate finance. Retrieved from 
https://extranet.sioe.org/uploads/isnie2015/li_dang.pdf

Chue, S. N. (2012). Cash Holding, Capital Structure, and FF. Ph.D. Thesis, University of Nottingham.

Chughtai, S., Riaz, M., Noor, S., \& Zafar, N. (2011). Free Cash Flow Anomaly: Evidence from the Karachi. Interdisciplinary Journal of Contemporary Research in Business, 3(8), 550-569.

Coskun, M., \& Kulali, G. (2012). Comparative Due Diligence Analysis of Debt Capacity and Cost of Debt: Companies in Euro Area Versus Companies in Turkey. Journal of Business, Economics \& Finance, 1(3), 52-69.

Darabi, R., Mohamadi, S. G., \& Forozan, S. (2013). The Relationship between FF and Capital Structure Decisions. Research Journal of Applied Science, Engineering and Technology, 5(14), 3843-3850. https://doi.org/10.19026/rjaset.5.4534

DeAngelo, H., \& DeAngelo, L. (2007). Capital Structure, Payout Policy, and Financial Flexibility. SSRN Working Paper 916093. https://doi.org/10.2139/ssrn.916093

Gamba, A., \& Triantis, A. (2008). The Value of Financial Flexibility. The Journal of Finance, 63(5), 2263-2296. https://doi.org/10.1111/j.1540-6261.2008.01397.x

George, W. Y. (2010). The Impacts of Free Cash Flows and Agency Costs on Firm Performance. Journal of Service Science \&Management, 3(4), 408-418. https://doi.org/10.4236/jssm.2010.34047

Graham, J. (2000). How Big Are the Tax Benefits of Debt? Journal of Finance, 55, 1901-1924. https://doi.org/10.1111/0022-1082.00277

Handoo, A., \& Sharma, K. (2014). A study on the determinants of Capital Structure in India. Journal of IIMB Management Review, 26, 170-182. https://doi.org/10.1016/j.iimb.2014.07.009

Hays, A. F. (2009). Beyond Baron and Kenny: Statistical Mediation Analysis in the new Millennium. Communication Monographs, 76(4), 408-420. https://doi.org/10.1080/03637750903310360

Hess, D., \& Philipp, I. (2014). How Much Is Too Much?: Debt Capacity and FF. Working Papers. Retrieved from http://papers.ssrn.com/sol3/papers .cfm? abstract_id=1990259

Iqbal, A., Hameed, I., \& Ramzan, N. (2012). The Impact of Debt Capacity on Firm's Growth. America Journal of Scientific Research, 59, 109-115.

Kolker, K. (2013). Debt Capacity for Short-Term financing In Financial Crises. The Bonn Journal of Economics, 2(1), 31-42.

Lemmon, M. L., \& Zender, J. F. (2010). Debt Capacity and Test of Capital Structure Theories. Journal of Quantitative Financial Analysis, 45, 1161-1187. https://doi.org/10.1017/S0022109010000499

Liow, K. H. (2010). Firm Value, growth, profitability, and Capital Structure of listed real estate companies. Journal of Property Research, 27(2), 119-146. https://doi.org/10.1080/09599916.2010.500459

Lozano, M. B. (2012). Analyzing the effect of excess Cash accumulation on financial decisions. Applied Economics, 44, 2687-2698. https://doi.org/10.1080/00036846.2011.566195

Ma, C., \& Jin, Y. (2016). What Drives the Relationship Between FF and Firm Performance: Investment Scale or Investment Efficiency? Evidence from China. Emerging Markets Finance \& Trade, 52, 2043-2055. https://doi.org/10.1080/1540496X.2015.1098036

Marchica, M. T., \& Mura, R. (2010). FF Investment Ability, and Firm Value: Evidence from Firms with Spare Debt Capacity. Financial Management, 39, 1339-1365. https://doi.org/10.1111/j.1755-053X.2010.01115.x

Md Rashidul, I., Man, W., \& Dewri, L. V. (2019). FF - A Synthesis of Literature Review. International Journal of Accounting and Financial Reporting, 9(1).

Md Rashidul, I., Man, W., \& Zulfiqar, M. Z. (2019). Impact of Corporate Governance on Firms' FF in the Emerging Economy: Evidence from Bangladesh. International Journal of Accounting and Financial Reporting, 9(4). https://doi.org/10.5296/ijafr.v9i4.15370

Mirkhalili, T. A., \& Mahmoudabadi, H. K. (2018). The Effect of FF on Financial Behavior of Companies Listed in the Tehran Stock Exchange. American Journal of Industrial and Business Management, 8, 143-155. http://www.scirp.org/journal/ajibm

Modigliani, F., \& Miller, M. H. (1963). Corporate income taxes and the Cost of Capital: A Correction. The American Economic Review, 53(3), 433-43. 
Ogden, J. P., \& Shanhong, W. (2013). Reassessing of the effect of growth on Leverage. Journal of Corporate Finance, 23, 182-195. https://doi.org/10.1016/j.jcorpfin.2013.08.008

Poulsen, M., Faff, R., \& Gray, S. (2013). Financial Inflexibility and the Value Premium. International Review of Finance, 1(3), 327-344. https://doi.org/10.1111/irfi.12010

Setianto, R., \& Kusumpautra, A. (2017). Corporate finance flexibility, investment activities, and cash holding: Evidence from Indonesia. Indonesian Capital Market Review, 9, 75-85. https://doi.org/10.21002/icmr.v9i2.7470

Slehat, Z. A. F. (2019). The Impact of the FF on the Performance: An Empirical Study on a Sample of Jordanian Services Sector Firms in Period (2010-2017). International Journal of Business and Management, 14(6). https://doi.org/10.5539/ijbm.v14n6p1

Talebnia, G., Valipour, H., \& Shafiee, S. (2010). Empirical Study of the Relationship between Ownership Structure and Firm Performance: Some Evidence of Listed Companies in Tehran Stock Exchange. Journal of Sustainable Development, 3(2). https://doi.org/10.5539/jsd.v3n2p264

Xinshu, Z., Lyndh, J. G. JR, \& Oimei, C. (2010). Reconsidering Baron and Kenny: Myths and Truths about Mediation Analysis. Journal of Consumer Research, 37, 197-206. https://doi.org/10.1086/651257

Yung, K., D-Q. D. L., \& Jian, Y. (2015). The value of corporate FF in emerging countries. Journal of Multinational Financial Management, 32-33, 25-41. https://doi.org/10.1016/j.mulfin.2015.07.001

\section{Copyrights}

Copyright for this article is retained by the author(s), with first publication rights granted to the journal.

This is an open-access article distributed under the terms and conditions of the Creative Commons Attribution license (http://creativecommons.org/licenses/by/4.0/). 